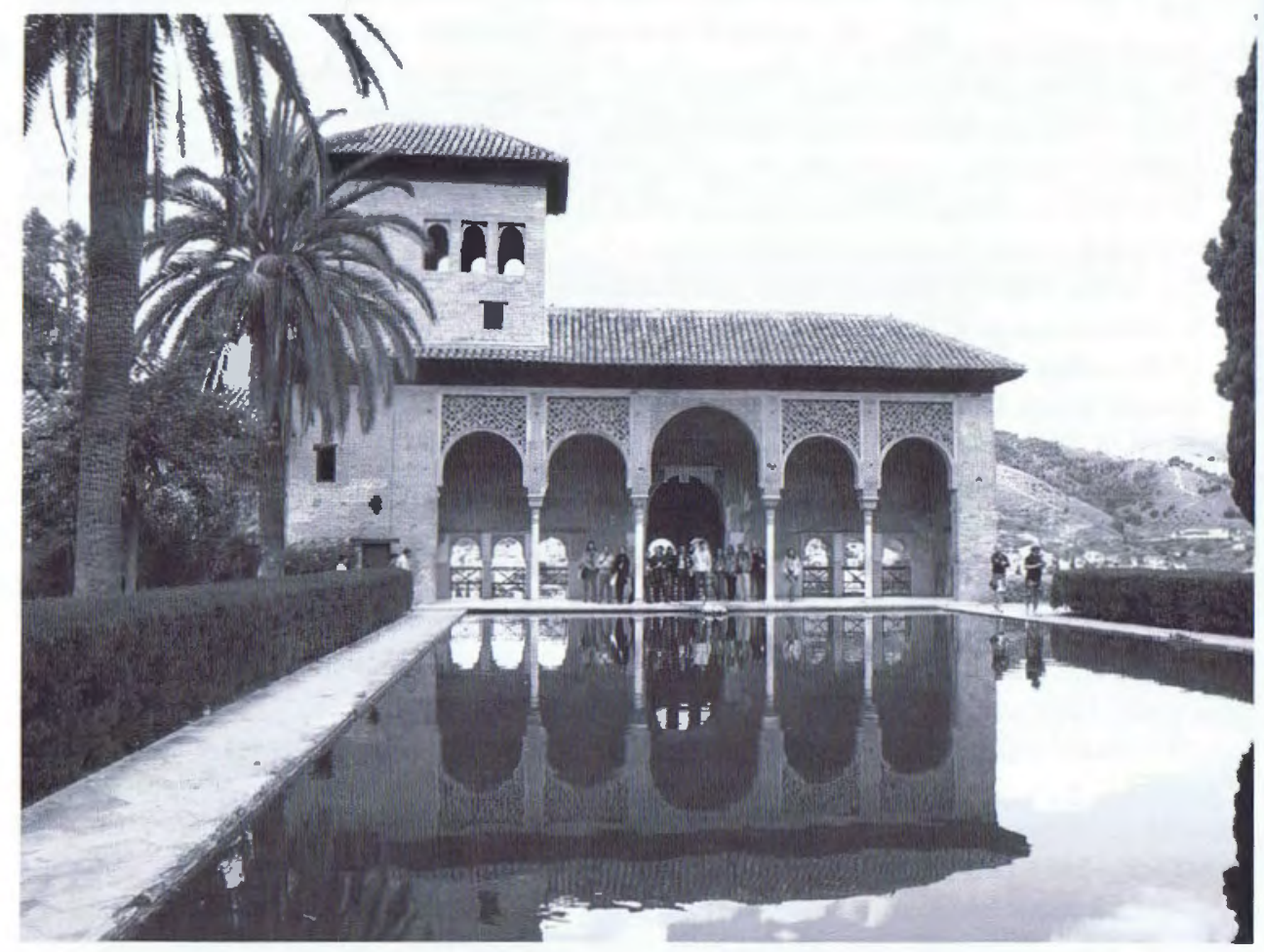

\title{
SPAIN UNDER THE VENICE CHARTER
}

\section{CAMILLA MiLETO}

Universitat Politècnica de València

\section{FERNANDO VEGAS}

Universitat Politècnica de Valèncla

Figure 1. Partal Pavilion at the Alhambra of Granada, Spain, restored by Leopoldo Torres Balbas in the 1920s. (Vegas and Mileto) 


\begin{abstract}
This article examines the Venice Charter's influence on the evolution of restoration in Spain in the interesting period that bridges the gap between Francoism and the dawn of democracy. Under the organizational structure that prevailed during Francoism, the restoration of monuments in the whole state was assigned to seven specialired architects who engaged in a stylistic approach. With the subsequent dawn of democracy, the field of monument restoration opened to a large range of non-specialized architects who applied ideas of critical restoration theory. This blatant dichotomy led to a diverse interpretation of the Venice Charter that this text strives to analyze from the vantage point of its actors, starting with the work of the participants in the Second International Congress of Architects and Technicians of Historic Monuments and continuing with the protagonists of the discipline of restoration in this country who followed after them.
\end{abstract}

Any discussion of restoration in Spain around 1964 inevitably points to a very peculiar moment in the country's history. The first three decades of the twentieth century had represented an extremely fruitful moment for Spanish restoration, which, through figures like Leopoldo Torres Balbás (Fig. 1) or Jeroni Martorell, was quite informed regarding international debates. Leopoldo Torres Balbás in particular was permanently in touch with Gustavo Giovannoni, and he had participated in drawing up the Athens Charter, which was put into practice in Spain with the Heritage Law of 1933.

But in 1936, the outbreak of the Civil War nipped the new ideas in the bud and silenced the people who were implementing them, many of whom (including Torres Balbás) suffered political consequences. The Civil War ended in 1939, leaving in its wake serious destruction of Spain's architectural heritage and of the cultural world as a whole. The following years saw frenetic reconstruction activity that could have involved a worthwhile opportunity to reflect about restoration principles and criteria. Despite the dramatic situation, the post-Civil War period in Spain could have advanced the theoretical development of the heritage discipline, as it did in Italy with professionals of the caliber of Roberto Pane or Pietro Gazzola. These necessary reflections, together with Pane and Gazzola's reconstruction and restoration work after World War II, were partly responsible for the role the two men played in the organization of the Second International Congress of Architects and Technicians of Historical Monuments in Venice in 1964. Above all, they were key to the revision of the Athens Charter, which ended with the production of the Venice Charter.

The Spanish situation, however, was very different. Franco's regime imposed the principles of tradition and order, aborting any form of innovation that might involve free 
thought or endanger the dictatorship and public order. After 1939, Spain turned its back on the rest of the world. Under what was known as autarchy, the country entered a phase of intellectual lethargy that kept it outside the advance of international thinking.

In the early 1960s, Spain timidly began to open up and establish a relationship with the rest of the world. In 1964, twenty Spanish architects turned up in Venice to take part in the Second International Congress of Architects and Technicians of Historical Monuments. A look at the professional profile and career of these architects helps us understand the situation of restoration in Spain prior to the Venice Charter and see the extent to which this document influenced the country later (see appendix for biographies of these architects).

\section{Twenty Spaniards at the Second International Congress of Architects and Technicians of Historical Monuments in Venice in 1964}

The Second International Congress of Architects and Technicians of Historical Monuments, which was sponsored by UNESCO and held in Venice in May 1964, led to the publication of a document as important as the Venice Charter. Of the conference's 622 participants, twenty came from Spain. ${ }^{1}$ Of those twenty, only eight contributed a paper. ${ }^{2}$

Gabriel Alomar Esteve delivered a lecture of a general nature that considered the challenges of restoring neglected buildings and the difficulties involved in their preservation and reuse. ${ }^{3}$ His lecture comprised three parts: the religious use of buildings such as monasteries and convents (although their new use does not solve the funding for their preservation); the cultural use of some monumental buildings, including castles or convents, as the headquarters of cultural institutions (archives, foundations, etc.); and finally, the conversion of some monuments into paradores (hostels) or state-owned hotels for tourist purposes. The restoration of monumental buildings (castles or monasteries) as tourist complexes was one of Spain's main courses of action in the 1960s. It was one of the signs of the initial opening up of the dictatorship to the outside world, but the projects served a greater symbolic purpose than simply the restoration of historic buildings for history's sake; rather, they were interventions intended to give the image of a folkloric Spain for tourists. The subject addressed by Alomar Esteve regarding the new use of historic buildings was no doubt of interest at the Venice congress, as the organizers stated at the opening of the event and as recorded in Article 5 of the Venice Charter. ${ }^{4}$ Yet, the implementation of these rehabilitation projects was a far cry from the philosophy that the debate wished to air.

Adolfo Florensa Ferrer spoke about the intervention to rehabilitate the remains of the Roman wall in Barcelona, which was carried out by repairing small sections of the wall at a time to permit access to or visibility of these structures without actually leaving them freestanding. ${ }^{5}$ In his lecture, Ferrer underscored the relationship between the restoration of monuments and town planning. This subject was of special interest at the time for the event's organizers, Roberto Pane and Pietro Gazzola, as evidenced by its direct inclusion in the first article of the Venice Charter. ${ }^{6}$

Manuel González Varcárcel spoke about his interesting experience as architect of the 
General Department of Fine Arts in the city of Toledo, which was declared a monumental site. ${ }^{7}$ His interventions in the city of Toledo were not limited to the most important monuments; rather, he attempted to include the city as a whole, with its streets and squares, and to enhance nighttime views of the city with spotlights. In the second paper that González Valcárcel presented, he spoke again of the need to provide a suitable use for the buildings restored, echoing the message of Gabriel Alomar Esteve. ${ }^{8}$ The uses recommended by González Valcárcel were cultural, including archives, museums, or accommodations for tourists, as in the case of the paradores.

Francisco finiguez Almech presented a paper of a general character about rehabilitating monuments as environmental sites, and he proposed different cases of large isolated monuments, squares, and historic centers to be preserved because of their overall value. ${ }^{9}$ This paper clearly revealed the organizers' interest in the protection of a landmark's context and not simply the monument itself. This perspective, which was favored by Giovannoni, had already been included in the 1931 Athens Charter and was addressed in Article 6 of the Venice Charter.

Luis Menéndez-Pidal presented the case study of the restoration in the Guadalupe Monastery (Cáceres). ${ }^{10}$ He spoke of his restoration criteria by describing the elimination of the later layers of a building, which he described as "parasite constructions" that distorted the beautiful façade of the monastery. This viewpoint blatantly flouted the principle expressed in Article 11 of the Venice Charter, which calls for the preservation of all phases of a building's history. This principle allows for the removal of a layer in only extremely exceptional cases and never when linked to the free will of the author of the project. Moreover, Luis Menéndez Pidal's interventions frequently included important transformations of the building in the name of the search for a typology or elements that could characterize it, a significant departure from the spirit of Article 9 of the Venice Charter.

Francisco Pons-Sorolla Arnau presented the case study of the historic center of Portomarín (Lugo). ${ }^{11}$ The significance of Portomarin relates to the relocation of sites, which Article 7 of the Venice Charter describes as a type of intervention that must be avoided unless absolutely necessary. Francisco Pons-Sorolla moved four monuments in Galicia, three of which were moved due to the imperative necessity of building hydroelectric dams: the church of Monfero Monastery (La Coruna), which was relocated in 1951; the Romanesque churches of San Juan de Cova (1953-54) and San Esteban de Chouzan (1957), both in Carballedo (Lugo); and finally, the important intervention carried out on the medieval site in Portomarín (Lugo) between 1960 and 1964. The move of this medieval settlement, which was located on the Camino de Santiago and strongly associated with this location, comprised the relocation of some (not all) of the most significant buildings. The project did not reproduce the whole settlement, so as not to create a distorted image of the Camino de Santiago that ran through the original site. The most spectacular move was the church of San Juan in the center of the town, which was moved piece by piece; once it was reconstructed in its new location, it was cleaned and repaired, including the coping. ${ }^{12}$

Ricardo Calvet Serra (a technician at the Diputación de Lérida) presented a paper 
about the use of reinforced concrete in the restoration of historic buildings, thus addressing another interesting debate included in the Venice Charter: the use of modern techniques instead of traditional ones. ${ }^{13}$ As evidenced by the title of this paper, Calvet Serra suggests the use of reinforced concrete for the structural reinforcement of monuments because of the advantages that this material provides, including adaptability to form, adherence to stone, a monolithic character, and the dual possibility of filling small gaps or covering large areas with a small amount of material. To support his thesis, Serra gives the example of the towers of Burgos Cathedral: one tower was reinforced with iron, which later caused conservation problems, whereas the other tower was consolidated with reinforced concrete, producing excellent results. Serra's paper, which reflects total faith in reinforced concrete, is more akin to the recommendations of the 1931 Athens Charter than the Venice Charter, where modern techniques were deemed to be a secondary option to be used in cases where traditional techniques were ineffective. The Venice Charter does not recommend such modern techniques as a priority. Nevertheless, the ambiguity of Article 10 of the Venice Charter has always generated diverse interpretations.

Miguel Oliva Prat proposed an interesting revision of the restoration projects in the province of Gerona. These ventures included both archaeological remains and important monuments, as in the case of the Rodas Monastery. ${ }^{14}$ Nevertheless, the paper has an eminently historical tone, focusing more on the history of the monuments than on the actual intervention criteria.

Other architects and architectural conservators appear on the list of participants in the conference, but they either did not present papers or failed to submit texts for publication in the records. Among them: Joaquin Ros de Ramis, Monument Conservator of the Barcelona Council; José Secarra Balasch, architect; Ángel Majon Sudor, architect; and Antonio Sas Llaurado, architect. In addition, there were another two architects, who, despite having led many restoration projects, did not present papers at the congress. This was perhaps due to their age, the first because he was old (72 in 1964) and the second because he was young (34 in 1964). The older architect, Anselmo Arenillas Álvarez (1892-1979), was an architectural conservator whose work has been partly forgotten for a time. He was, however, in charge of restoration in a large area in the north of Spain in the regions of Castilla y León and Cantabria, a region that includes the monastery of Santa Maria La Real en Palencia, which deserves special mention (1964). ${ }^{15}$ The younger architect, Juan Bassegoda i Nonell (1930-2012), was also a professor at the Barcelona School of Architecture, where he held the Gaudi chair from 1968 until he retired in 2000 . He was involved in the restoration of several buildings by Catalan architect Antoni Gaudi, including the Casa Batlló, Parque Guell, Pabellones Güell, Casa Calvet, Crypt of the Colonia Guell, the gardens of Can Artigas, and more. Juan Bassegoda i Nonell was the only Spaniard who signed the Venice Charter.

\section{The Historic and Administrative Context}

Five of these architects were assigned to a region according to the monument management system that was adopted by the Spanish Administration by virtue of the Royal Decree of 


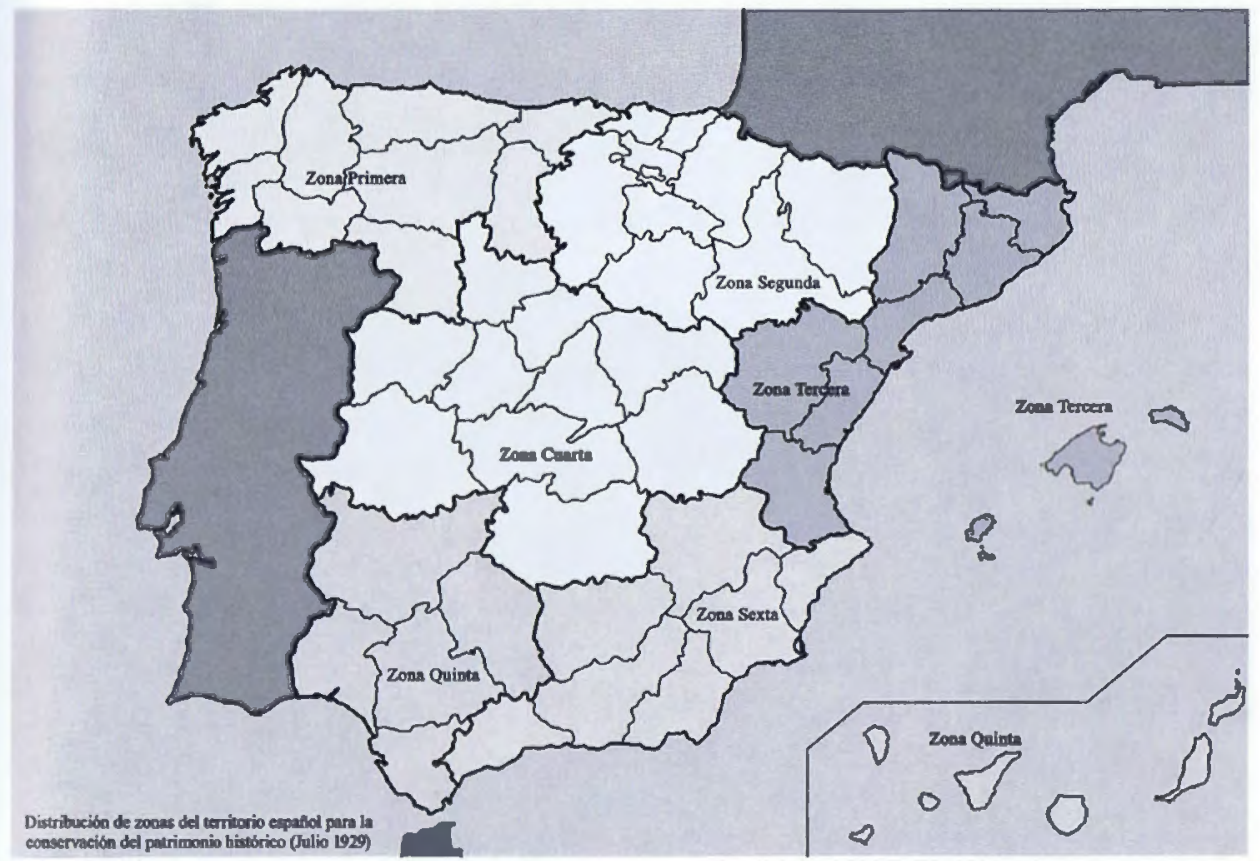

Flgure 2. A map showing the first division of Spanish territory into zones-a system thought to control the management and intervention of monuments from the Ministry of Public Instruction and Fine Arts, 1929. (Vegas and Mileto)

July 26, 1929. This fact allows us to contextualize their work in the history of the country and the administration of monuments. As a centralized agency under the Ministry of Public Instruction and Fine Arts, the Service of Architectural Conservation was based on a system to control the preservation management and intervention of monuments according to the division of Spanish territory into zones. Spain was divided into six zones, and each region had a Head Architect of Monuments who saw to the restoration of all the monuments in his own territory. This system, created so that restoration would be carried out only by architects who were highly specialized in the field of monument restoration, lasted, with some reforms, until 1978. This zone control system produced a heritage policy with centralized governmental control of the criteria put into practice. ${ }^{16}$

The architects selected in 1929 to cover the six regions (Fig. 2) were well-known figures in the sphere of monument restoration at the time, and were often joined by their young disciples: Alejandro Ferrant (zone 1: Galicia, Asturias, and León); Teodoro de los Ríos, replaced in 1933 by Francisco Iñiguez (zone 2: Euskadi, Navarra, La Rioja, Zaragoza, Aragón, Burgos, and Soria); Jeroni Martorell (zone 3: Baleares, Cataluña and Valencia, and Teruel); Emilio Moya Lledós (zone 4: Castilla la Vieja); Pablo Gutiérrez Moreno, replaced immediately by José María Rodriguez Cano (zone 5: Western Andalusia, Extremadura, and the Canary Islands); and Leopoldo Torres Balbás (zone 6: Eastern Andalusia and Murcia, Albacete, and Alicante). As a result of the political changes of the early 1930s, the zones 


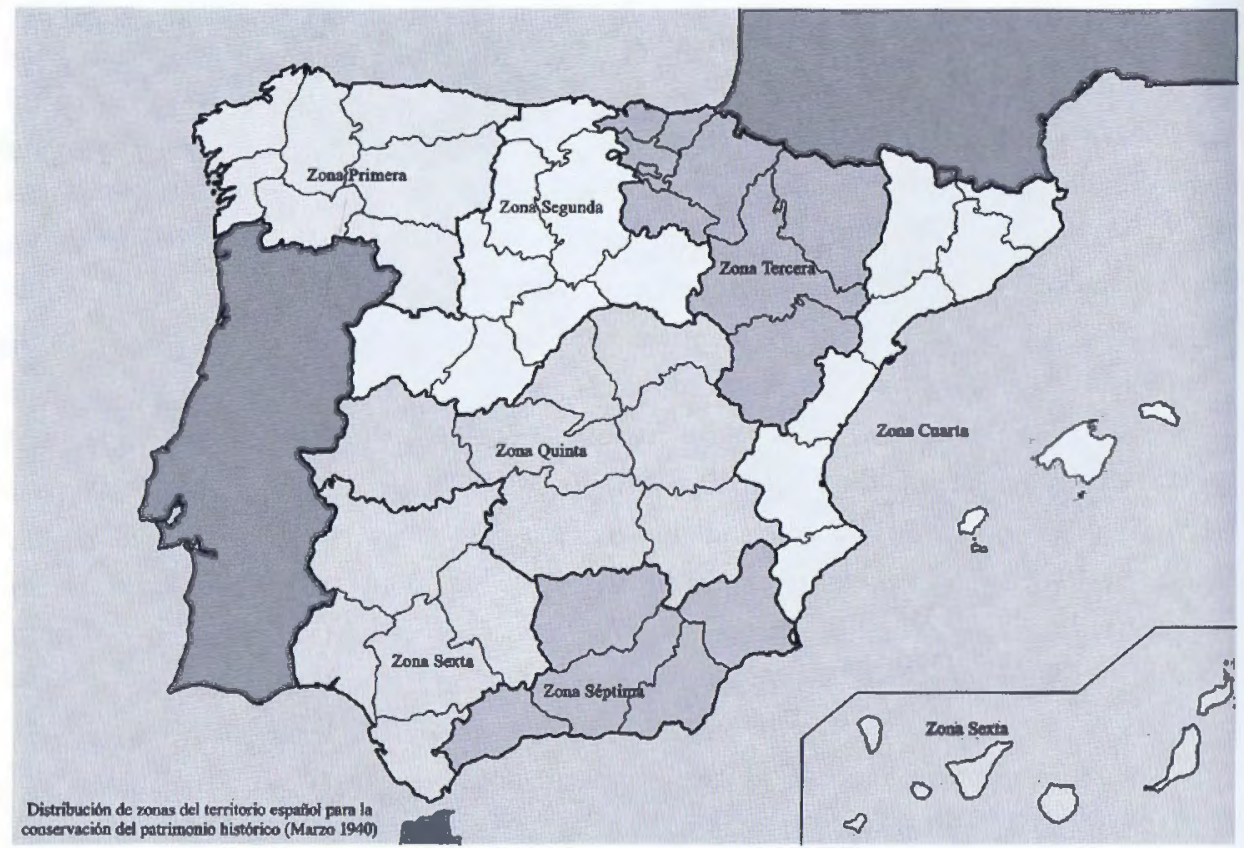

Figure 3. A map showing the subsequent division of Spanish teritory into zones to control the management and intervention of monuments after the Spanish Civil War, 1940. (Vegas and Mileto)

were redistributed in 1936, and several architects were dismissed and replaced due to blatant political incompatibility with the new regime. New appointed architects included Francisco Íniguez Almech, Constantino Candeira Pérez, and Félix Hernández Giménez. Around this same time, the Law of Protection of National Artistic Assets was prepared. It was largely influenced by the terms of the Athens Charter, which was drawn up in 1931, and its approval on May 13, 1933, marked a very important moment in the designation and preservation of Spanish monuments. ${ }^{17}$

Notwithstanding the great unrest the Civil War (1936-39) caused in Spain, the system of regional architects continued until 1978 when the new democratic constitution was implemented. Over the years, the zones were adjusted (increasing from six to eight), and the head architectural conservators and their assistants changed according to both the personal needs of the architects themselves as well as political changes. The most important change took place in 1940 and was strongly linked to the architects' political inclinations regarding Franco's regime (Fig. 3). At that time, the following architects were appointed: zone 1, Luis Menéndez Pidal (architectural conservator) and Juan González Cebrián (assistant); zone 2, Anselmo Arenillas (architectural conservator); zone 3, Manuel Lorente Jorquera (architectural conservator) and Arístides Fernández Vallespin (assistant); zone 4, Alejandro Ferrant Vázquez (architectural conservator) and Rafael Martínez Higueras (assistant); zone 5, José Maria Rodriguez Cano (architectural conservator) and 
José Manuel González-Valcárcel (assistant); zone 6, Félix Hernández Jiménez (architectural conservator) and José Menéndez-Pidal (in 1958); and zone 7, Francisco Prieto Moreno (architectural conservator) and José Tamés Alarcón (assistant).

The next important date in Spanish history is 1959 , when autarchy came to an end and the Spanish state opened up to the outside, leading to economic development in the years that followed. Almost in parallel, in 1958, the General Department of Fine Arts set up an anthological exhibition with the meaningful title "Twenty Years of Monument Restoration in Spain," which compiled the interventions carried out under the early years of the Franco regime, including the country's painstaking postwar reconstruction. ${ }^{18}$ The zone architects who occupied their posts in 1958 are the same ones we find in 1964. Surprisingly, most of the head architects in 1958 comprised those who were initially appointed in 1940, a continuity that points to the stability, or rather the ultraconservatism, of preservation policy and criteria during those years. After the changes in 1940, the transitions in personnel include the appointments of Francisco Pons Sorolla in 1945 (assistant in zone 1), Luis Cervera Vera in 1952 (assistant in zone 2), and Fernando Chueca Goitia, also in 1952 (assistant in zone 3).

\section{The Venice Charter: A Watershed?}

In Spanish history, 1964 constituted a new political era in a dictatorship that was beginning to open up and make contacts, especially of an economic and commercial nature, with the outside world. The architects who went to the congress in Venice were therefore ambassadors of a new political era that did not, however, favor new criteria in the sphere of heritage rehabilitation. As we have seen above, the zone architects were at a complete standstill, with ideas and criteria that had not changed since 1940. When the Civil War ended in 1939, the new Francoist State addressed above all the reconstruction of a country that had been physically and psychologically devastated by years of infighting. The idea of postwar reconstruction implied the physical reconstruction of buildings, but it also constituted the construction of a history and an ideology. Restoration projects adhered to the guidelines of Francoist ideology, so that the buildings that represented the achievements of the winning side were prioritized. This system placed focus on the reconstruction of the Alcázar de Toledo (Fig. 4); state-owned buildings or those owned by associations that supported the regime; and towns that had been badly damaged by the republican side in an attempt to hold off Francoist supporters, which were known as "towns adopted by the caudillo [leader]." 19

The choice of buildings to be restored, as well as the preservation criteria that were implemented, clearly demonstrate that, beginning in the late 1930 s, restoration was used in Spain as a tool to shape and transform memory that was linked in this case to the presence of a totalitarian regime that applied a strict ideological control. ${ }^{20}$ The post-Civil War interventions strove to convey a necessary return to tradition and order in society, as well as to transfer the image of an imperialist Spain recovering the architectural forms of the seventeenth century. Thus, criteria of stylistic restoration were applied by removing 


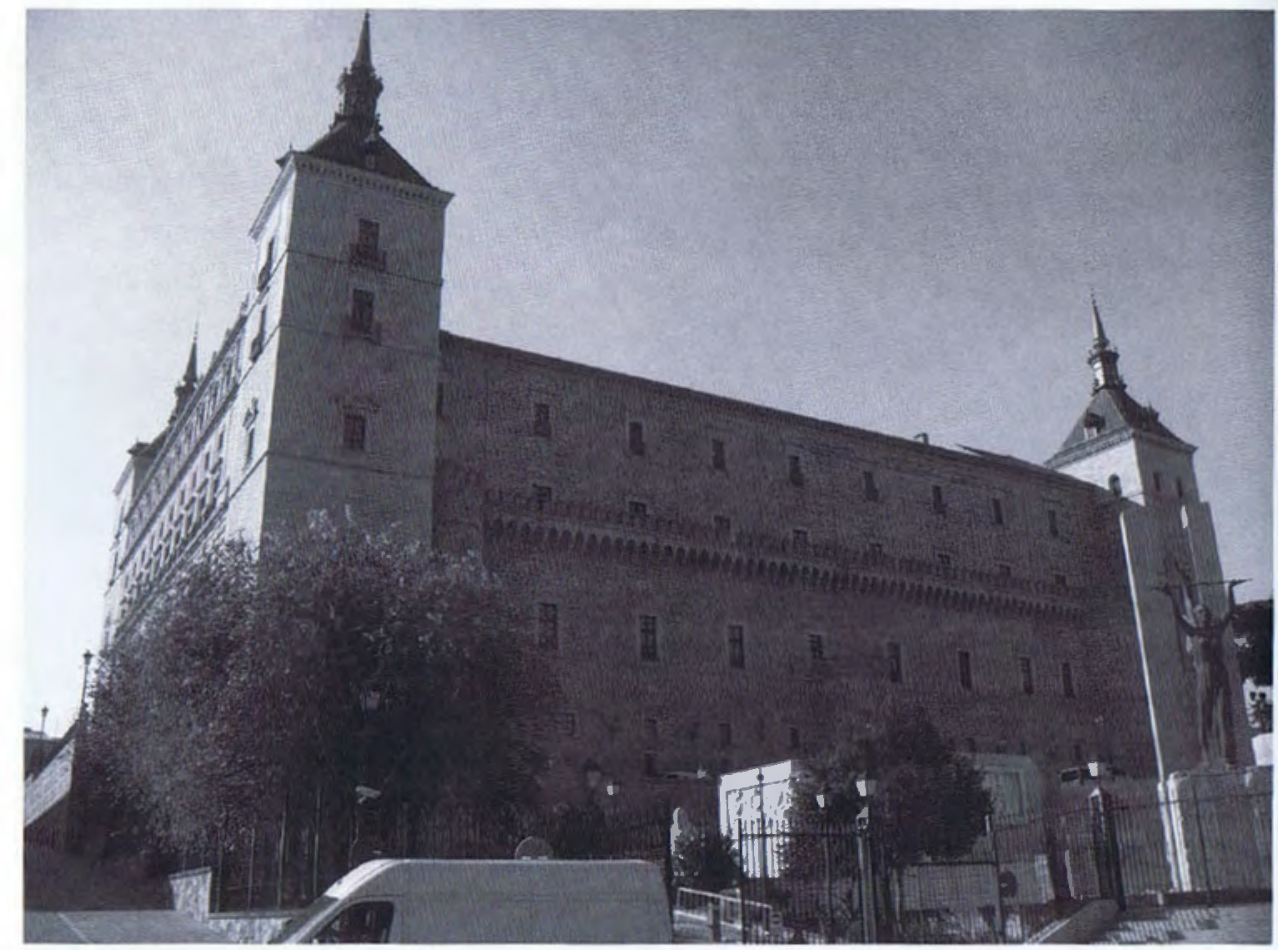

Figure 4. The reconstruction of the Alcazar of Toledo represented the achievements of the winning side of the Spanish Civil War. (Vegas and Mileto)

later additions and reconstructing missing sections, often according to a free interpretation that was designed to make the building easier to understand. ${ }^{21}$ The aim was above all to recover the nationalist splendor of medieval architecture and the purity of the ecclesiastical style, in order to transmit the values of exemplary Catholic doctrine and imbue the Spanish people with the principles of Franco's regime. Work at every scale was conceived to uphold the power and prominence of the state. In Galicia, for example, architect Francisco Pons-Sorolla oversaw the relocation of monuments, clearing the way for the construction of large dams that produced hydroelectric power and were also used as political propaganda, boasting of the state's investments to improve the citizens' living conditions.

The projects that the Spanish architects presented at the Venice congress in 1964 clearly illustrate the preservation practices in Spain in those Francoist years, which were often a far cry from what was happening elsewhere in contemporary Europe. Three generations of architects were present on this occasion. The first was represented by very experienced elderly architects who were nearing the ends of their careers: Adolfo Florensa (75 years old); Anselmo Arenillas (72); Luis Menéndez Pidal (71); and, although slightly younger, Francisco friguez (63). The second group was represented by experienced architects at the height of their career, including Gabriel Alomar (54), Manuel González Valcárcel (51), and Francisco Pons-Sorolla (47). The third group included young architects and 
archaeologists such as Miguel Oliva (42) and Joan Bassegoda (34). Despite the age difference between these architects, their policies were clearly quite homogeneous, and they fully coincided with the guidelines drawn up by the ideology of the regime.

This important event in 1964 no doubt exposed these architects to other approaches to architectural restoration, such as the work at the Hospital Mayor in Milan that Liliana Grassi presented. Yet, no important changes are evident in their preservation policies and interventions in the years that followed. ${ }^{22}$ For example, as with all of his work, Luis Menéndez-Pidal's restoration of the Pre-Romanesque buildings in Asturias followed the same very clear criteria. The monument was restored to its original appearance using the same materials as the original structure, both to fill in gaps and to reconstruct the missing sections; a suitable landscape was created for the building; and a reproduction of the interior was created for visitors to enjoy. ${ }^{23}$ These design standards, based on a study of historic and archaeological evidence to discover the original state of the building, were applied to all of Menéndez-Pidal's restoration projects in the 1940 s and 1950s (e.g., San Salvador de Priesca, 1937-42; San Julián de los Prados, 1939-40; San Pedro de Nora, 1940-64, and so on).

Even after the Venice congress-and sometimes more blatantly after the 1964 gathering-Menéndez-Pidal continued to apply restoration principles at odds with the standards of the Venice Charter and many contemporary European professionals. This included some of the same buildings that he had already worked on (e.g., San Julián de los Prados, 1970-79, and San Salvador de Valdediós, 1953-74, among others). ${ }^{24}$ Indeed, in the last stage of his life, he remained oblivious to the lessons learned in Venice, reconstructing entire portions of buildings based on insufficient and untrustworthy data. Among these works, we can mention: the reconstruction of the north chapel of San Salvador Church in Valdediós (1953-72), which imitates the existing chapel on the south; the construction of a freestanding narthex in the Church of San Pedro de Nora (1952-64), which replicates the one in Santullano; and the integral reconstruction of the Church of Santa Maria de Bendones (1958-71) based on scant archaeological data. ${ }^{25}$ All of these interventions produced an unusual and unnatural architectural homogeneity within each region that very strongly affected the historical interpretations of Pre-Romanesque architecture in Asturias.

Juan Menéndez-Pidal is characteristic of Spain's absolute stagnation and firm adherence to the old-school criteria of restoration. This inertia was evident in not only the older generation of architects attending the congress in Venice, but also the younger generations. These criteria remained unchanged until the arrival of democracy, as was apparent in the work by much younger architects like Francisco Pons-Sorolla or Fernando Chueca Goitia (1911-2004).

In Spain, the Venice Charter fell on very sterile land that did not absorb its core principles until many years later. This barrier existed not only in the sphere of interventions and the architects designing them, but also in the legislative sector. Whereas the Athens Charter had great influence on legislation related to Spanish heritage (including the Law of 1933), the Venice Charter did not follow the same course. Instead, the Law of 
1933 was not replaced until 1985, when the current Spanish Heritage Law was introduced after the advent of democracy. It took twenty years after the 1964 conference for the principles of the Venice Charter to make any mark on Spanish legislation.

\section{The Advent of Democracy and Freedom in Restoration}

Between the death of General Franco in 1975 and the approval of the new constitution in 1978, the administration began a transformation that greatly influenced Spain's architectural restoration practices in the following years. In 1977, the Ministry of Culture was created to serve as the entity with the power to manage and control the country's architectural heritage. Dionisio Hernández Gil was appointed director of the General Restoration Service of the Ministry of Culture, and he in turn appointed Manuel de las Casas and Antón Capitel as his direct collaborators within the Technical Service. At the time of their appointment, both men were project professors at Madrid University.

From then on, the course of restoration in Spain changed radically, and very soon, with the winds of democracy sweeping over the country, restoration projects were no longer under the control of a handful of zone architects. Instead, the number of architects collaborating with the General Restoration Service rose to five hundred. Not only did the number of architects involved increase, but also the number of projects carried out: between 1940 and 1977, a total of 6,801 projects were completed on 1,964 buildings; in contrast, in just the five years between 1978 and 1983, 1,900 projects were completed on 1,291 buildings. ${ }^{26}$ As Vitale points out, several significant observations can be made: first, the number of projects carried out each year increased, but above all, the number of buildings in proportion to the projects increased considerably; second, the state invested in different types of buildings, rather than concentrate all its efforts on the same important monuments. ${ }^{27}$ Furthermore, the Ministry of Culture did not intervene only on a larger number of monuments, but also on buildings and areas that had previously been unprotected, as in the case of historic town centers. ${ }^{28}$ This is perhaps the strongest indication that concept of heritage-and the range of buildings considered worthy of restorationbegan to change during these years to become more in keeping with the guidelines of the Venice Charter.

In 1985, the Law of Spanish Historic Heritage (Ley 16/1985) was passed; it adopted the ideas of the Venice Charter and finally marked a real revision of restoration practice in Spain, at least as far as legislation is concerned. This law, which is still in force, made a clear reference to the need to conserve the contributions of every period. It condemned stylistic or mimetic reconstructions, and stated that any necessary new elements must be clearly distinguishable from the historic fabric.29 The 1985 law transfers the power to make decisions regarding architectural heritage from the central administration to autonomous communities, spurring new localized heritage laws beginning in the late 1980 s and continuing until the late 1990s. This transfer of jurisdiction permits a greater use of public funding for local heritage assets, although it does allow for greater variation and discrepancies in preservation standards. ${ }^{30}$

Another outcome that should be addressed is related to the increase in the number 
of architects involved and the subsequently necessary increase in open-mindedness. Until this time, zone architects were specifically trained to perform architectural restoration in a stylistic manner. After the arrival of democracy, architectural restoration was no longer specified as a closed discipline. Thus, these projects suddenly did not require any special professional training, and individual ventures that had previously been marginalized were embraced as test cases for new interventions. ${ }^{31}$ This vindication was to become a necessary rupture from the Francoist period, and it marked an affirmation of modern mentalities that extended beyond the world of restoration. Traditional restoration was associated with the Francoist dictatorship, political propaganda, and narrow-minded values and principles, whereas unrestricted modern interventions, which often disregarded history, were seen as a manifestation of democracy, progress, and freedom.

This need for uncompromising modernity produced, on one hand, a clear separation between these two eras of restoration in Spain, and it indubitably paved the way for Spain to catch up after forty years of lethargy. Yet, as Javier Rivera points out, it also produced widespread indecision and disorientation among many of the young professionals who, without adequate preparation, were unaware of the minimum principles required in pursuit of creative freedom within the field of architectural restoration. ${ }^{32}$ The architects' lack of training was the natural result of a complete lack of training and education on the theories and practice of restoration. This deficiency lasted until our time, with only a few schools of architecture offering courses that provide solid knowledge of the discipline; most schools leave this subject matter to optional or postgraduate studies. ${ }^{33}$ This absence constitutes a serious flaw in the training of future architects whose professional duties can include preservation responsibilities for built heritage.

The 1980s were characterized, in some ways, by the interventions endorsed by the Ministry of Culture, which generally followed the guidelines of the 1985 Heritage Law, particularly in the restoration plans or programs for groups of buildings. This was evident in the program for the rehabilitation of nineteenth-century Spanish theaters, including the Teatro Rojas in Toledo, by Manuel de las Casas; the Teatro Principal in Medina de Rioseco, by G. Sánchez Hevia; and the National Cathedral Plan. Important interventions included the Toledo Cathedral, by Manuel and Ignacio de las Casas, and Cuenca Cathedral, by J. Ibániez, J. C. Palacios, and J. L. Alau. This period was also marked by the socioeconomic recuperation of historic town and city centers, with emblematic cases that range from Toledo's Tembleque Square, by M. Barbero, or the refurbishment of the houses on the River Onar in Gerona, implemented by E. Ansesa, J. Faix6, J. Fuses, and J. Viader. ${ }^{34}$

Alternatively, some commissions interpreted these internationally-accepted principles of restoration much more freely. They began to use the principles to rehabilitate buildings linked to new independent administrative structures, such as the seats of independent assemblies (e.g., the building for the Assembly of Extremadura, by Dionisio Hernández Gil) or the headquarters of the Professional Association of Architects in Gerona, Huelva, and Murcia. All of these projects comprised interventions in which new additions were often easily discernible and given conspicuous prominence. Finally, there were some outstanding restorations that were considered de auteur ("by the author"), which set an 


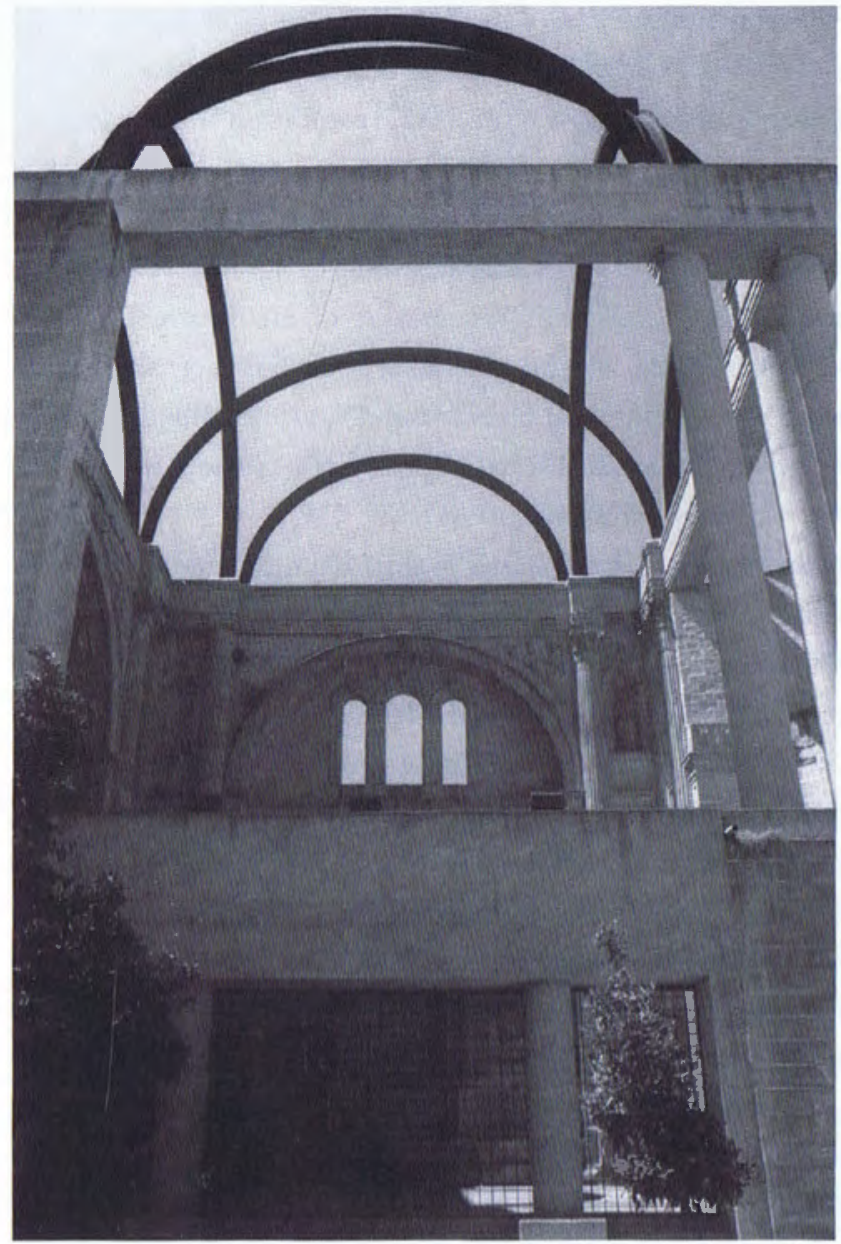

Figure 5. The Convento de San Francisco in Baeza, by S. Araujo and J. Nadal, serves as an example of the creative restoration "de auteur" typical of the first years of democracy in Spain after the death of Franco. (Elisa Rolle; CC 3.0)

example for creative interventions that were far removed from the historicist restorations reminiscent of Franco's days. ${ }^{35}$ Among these, it is worth mentioning the Convento de San Francisco in Baeza (Fig. 5), by S. Araujo and J. Nadal, or the Castle of Bétera by Francisco Jurado (Fig. 6). ${ }^{36}$

The confusion over restoration theory that arose in some sectors during these years was associated above all with the Ministry of Culture, which respected the recognized principles of restoration. Others contributed to the uncertainty by defending total expressive freedom in heritage interventions. Above all, the field was populated by young professionals who lacked specific training and adequate direction. This last factor finally resulted in attempts to establish a theory curriculum in the 1990s, based on the work of several authors' writings on the restoration of historic buildings. 


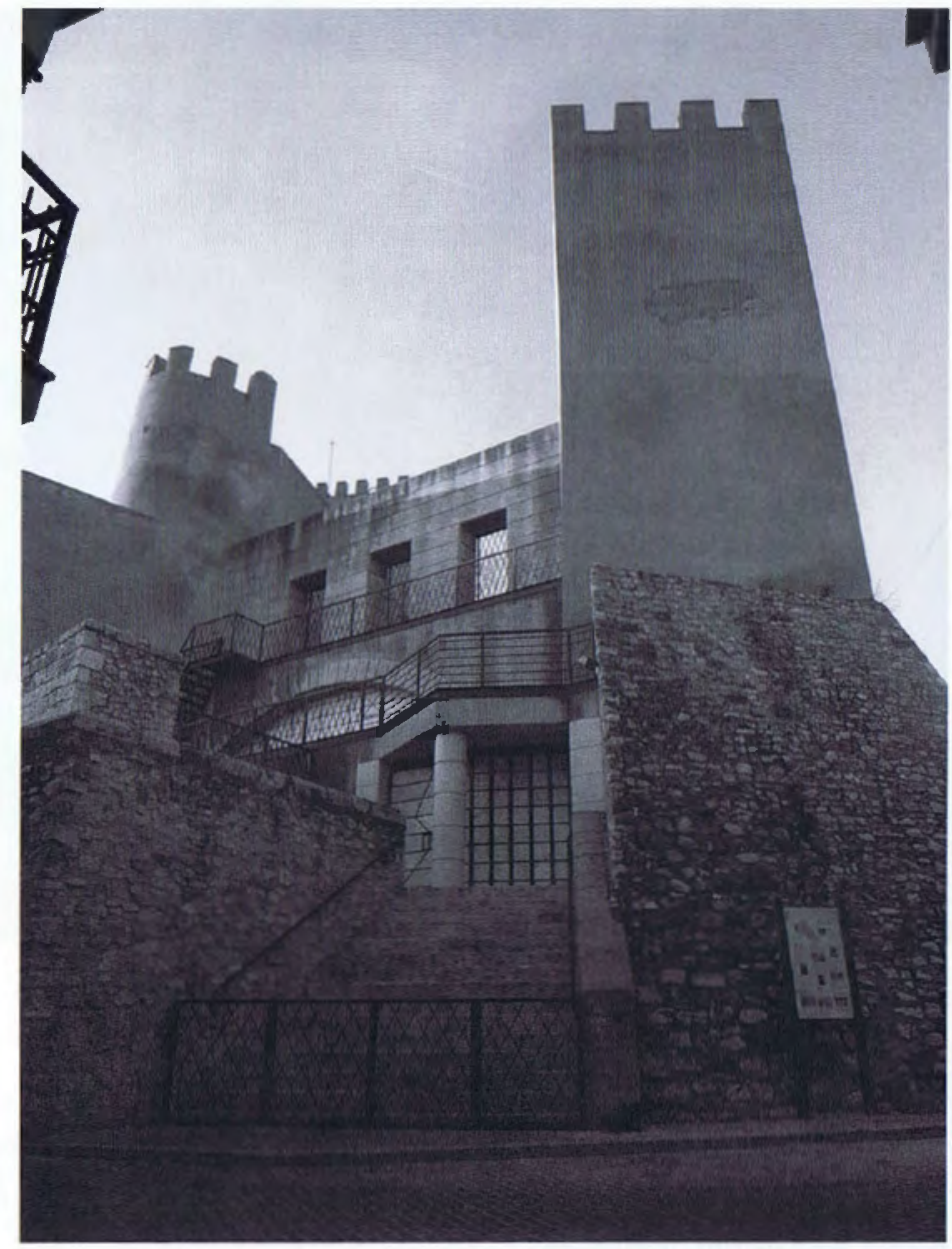

Figure 6. The restoration of the Castle of Bêtera by Francisco Jurado provides a representative example of the interventions in Spain in the 1980s. (Vegas and Mileto)

The foremost proponent in the years when creative importance was placed on adding new elements to historic buildings was undoubtedly Ignasi de Solà-Morales. Convinced of the value of "creative intervention" for the relevance of an architectural project, he argued for "neither conservation nor restoration: architectural intervention." De Solá-Morales himself took part in designing the new addition for the restored Teatro Liceu Theater, as well as the reconstruction of Mies van der Rohe's German Pavilion in Barcelona. ${ }^{37}$ This school of thought is also evident in the interventions by J. Navarro Baldeweg in the mills on the River Segura, the battlements of Palma, and the San Antonio church in Ibiza, by E. Torres and J. A. Martinez La Peña. ${ }^{38}$ Just as Solà-Morales argued in his writings, these projects unmistakably adhered to the principle of distinguishing between the old, historic building and any new additions. They do not abide by the former theory of Spanish 


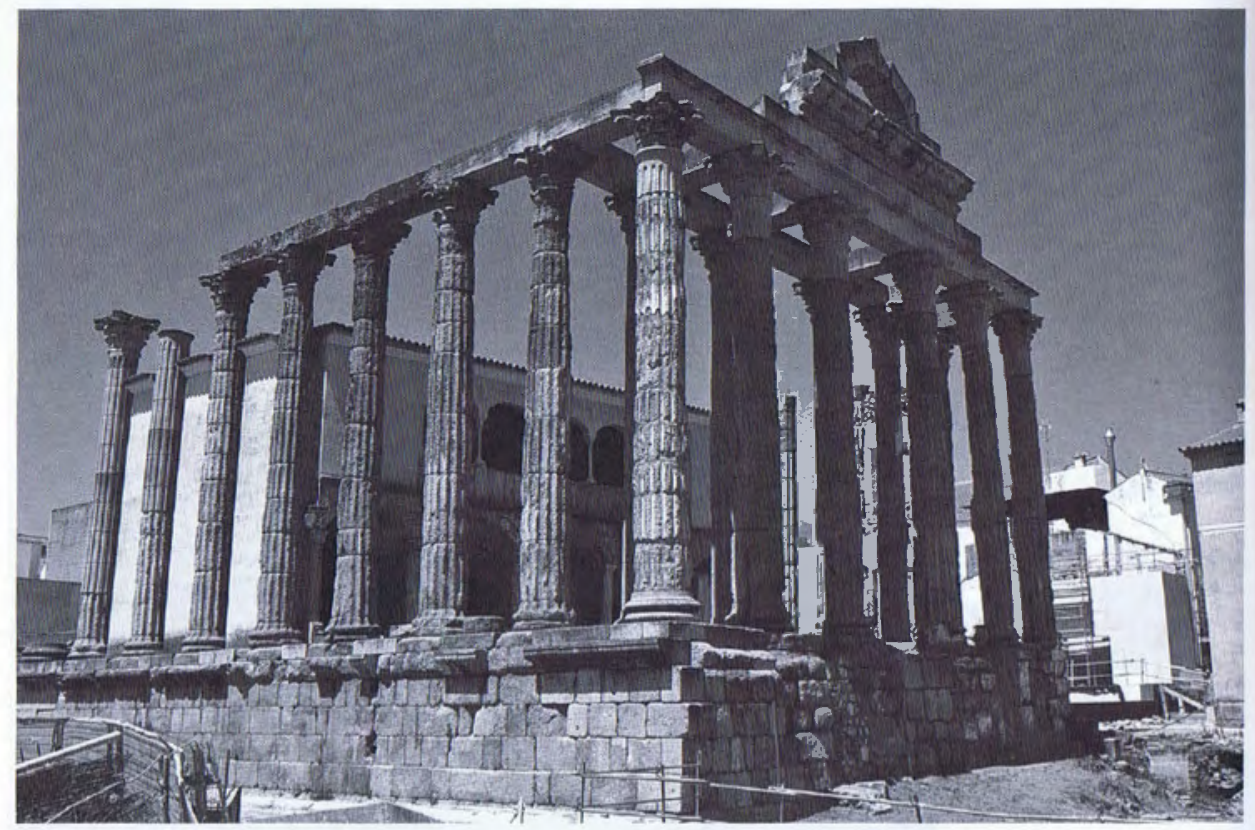

Figure 7. The intervention completed at the Temple of Diana in Mérida by Dionisio Hernández Gil was designed to restore and possibly interpret the structure's remains. (Juan Jesús; CC 3.0)

restoration projects in the Francoist era, which maintained that new elements should be blended with the historic fabric. Rather, the writings of Solà-Morales and the works of J. Navarro Baldeweg, E. Torres, J. A. Martinez La Peña, and others made sure to stand out with a very distinctive design.

Among those who support modern additions to historic buildings, we can also include Salvador Pérez Arroyo, who demonstrates greater sensibility toward the historic building, attempting to insert only those elements that are necessary to use the site. ${ }^{39}$ This approach is likely due to his close collaboration with Susana Mora. Arroyo tries to make these obviously modern elements fit in with the preexisting historic fabric, both in his choice of materials and the design. The best-known interventions of Salvador Pérez Arroyo and Susana Mora are the Monastery of Carracedo and the Monastery of San Pedro de Arlanza. ${ }^{40}$

On the other hand, there are authors who theorize and work on the idea of an intervention that stems from the building's history. These are interventions on archaeological sites that pursue the preservation and rehabilitation of the remains, with the possibility of interpreting them. This was true in the case of the interventions on the Temple of Diana in Mérida by Dionisio Hernández Gil (Fig. 7), the Roman theatre in Mérida by J. Menéndez-Pidal and Dionisio Hernández Gil, and the Roman theatre in Segóbriga by Antonio Almagro. It was also evident in the intervention in the Roman theatre of Sagunto 


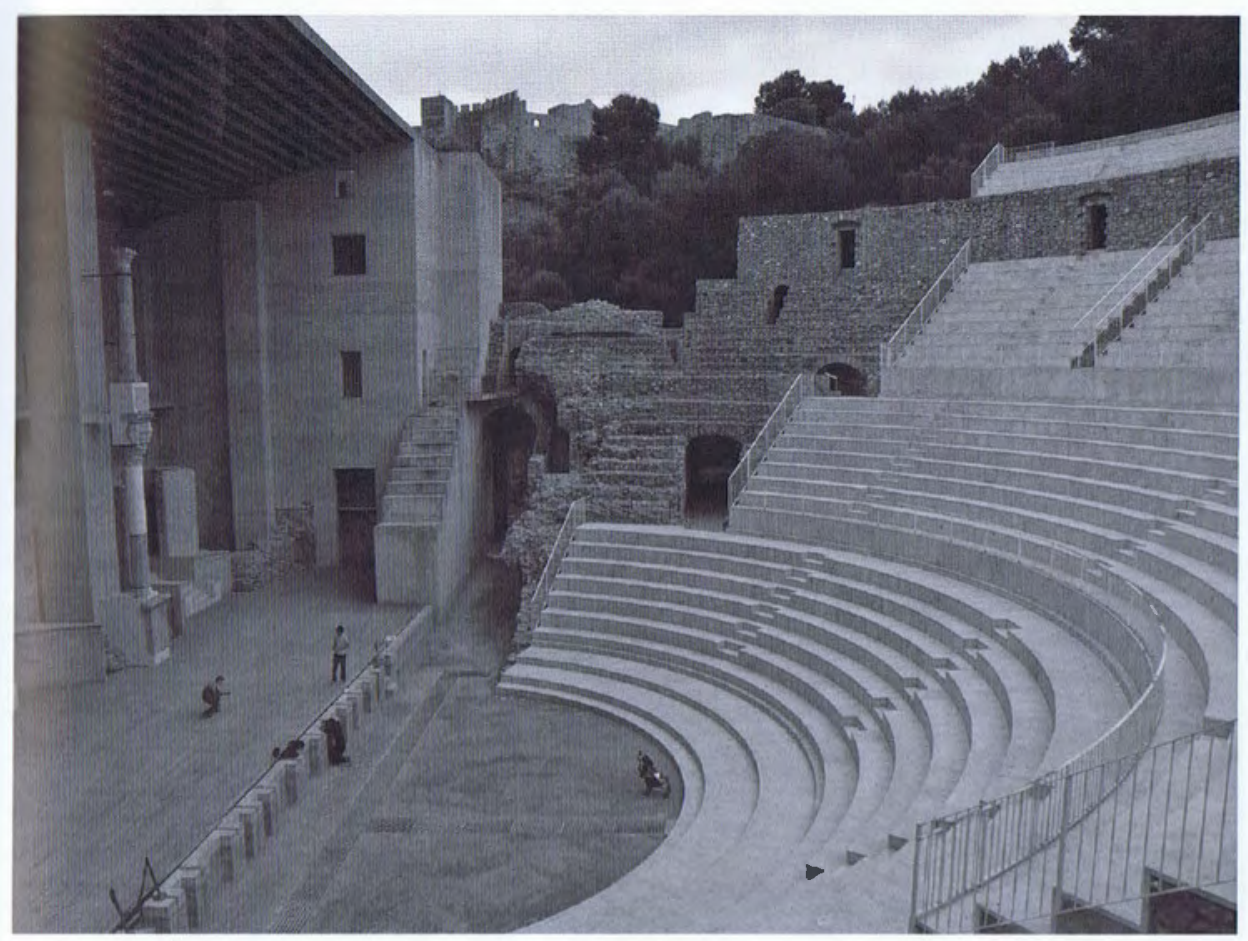

Figure 8. The intervention of the Roman theatre of Sagunto by F. Grassi and M. Portaceli represented a famous example of reconstruction in Spain in the 1990s. (Vegas and Mileto)

by F. Grassi and M. Portaceli (Fig. 8). ${ }^{41}$ At the same time, other restoration projects emphasized the restoration of the building based on its existing language, with the intervention planned according to an analogical language. This was the case in the work of Anton Capitel on the Church of Santa María la Real in Madrid, and that of Ignacio Linazasoro on the Church of Santa Cruz in Medina de Rioseco (Fig. 9). ${ }^{42}$ It is not a mere coincidence that this approach, more akin to the Venice Charter, came from the sphere of the Ministry of Culture.

Finally, it is worth mentioning the work of Antoni González Moreno-Navarro, head of the Heritage Service of the Diputación de Barcelona. He strove to establish a methodology for interventions on heritage buildings that would link the preliminary study to the intervention, and his work was very important in that it reached professionals engaged in restoration in Spain and raised their awareness. ${ }^{43}$ Despite the inflexibility of his methodology, the restoration works performed under his school of thought had diverse results. They ranged from primarily conservative interventions, such as the Church of San Pere de Serralonga or the cemetery of Castellnou de Bages, to much more invasive interventions, including the restoration of the Church of Casteldefels Castle. These interventions also included projects where new elements were added according to the critical restoration theory, as was the case for the apses of the Church of San Vicente in Malla. ${ }^{44}$ 


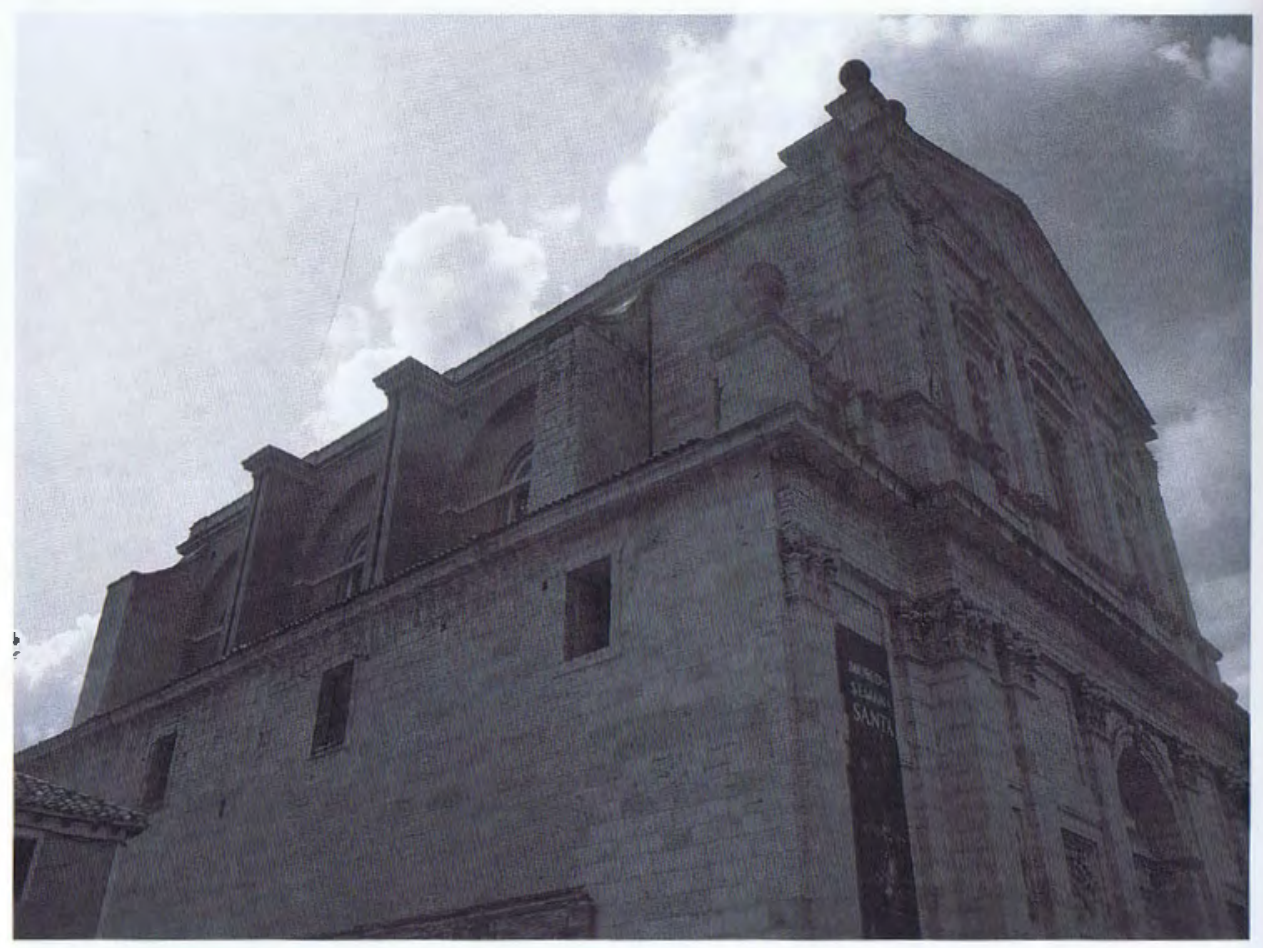

Figure 9. The intervention completed at the Church of Santa Cruz in Medina de Rjoseco by Ignacio Linazasoro was based on reinterpretation and the use of an analogical language to complete the missing parts of the ruined church. (Vegas and Mileto)

\section{Conclusion}

The Spanish architects who participated in the Second International Congress of Architects and Technicians of Historic Monuments in Venice in 1964 represented a nation that was very much steeped in the tradition of stylistic restoration, retrieved and glorified by a totalitarian regime that sought to legitimize its principles by means of its historic buildings. Therefore, in the years that followed, the Venice Charter did not receive a warm welcome in Spain. Only with Franco's death and the advent of democracy did the Venice Charter begin to be accepted in Spain. Twenty years after the approval of the charter, Spain passed the Heritage Law in 1985, which adopted all of the Venice Charter's principles as the basis for contemporary restoration and included them in its text.

Nevertheless, after the arrival of democracy, interventions followed different and often contradictory methods. Conflicting schools of thought emerged, with some that respected the historic building and its heritage value and others that prioritized the new intervention rather than the historic building itself. This confusion frequently led to dubious results for heritage purposes. In the panorama of Spanish restoration in the last two decades, a form of professional consensus has gradually emerged as many Spanish architects' preoccupation with cutting-edge modernity has eased. Today, the theory and practice 


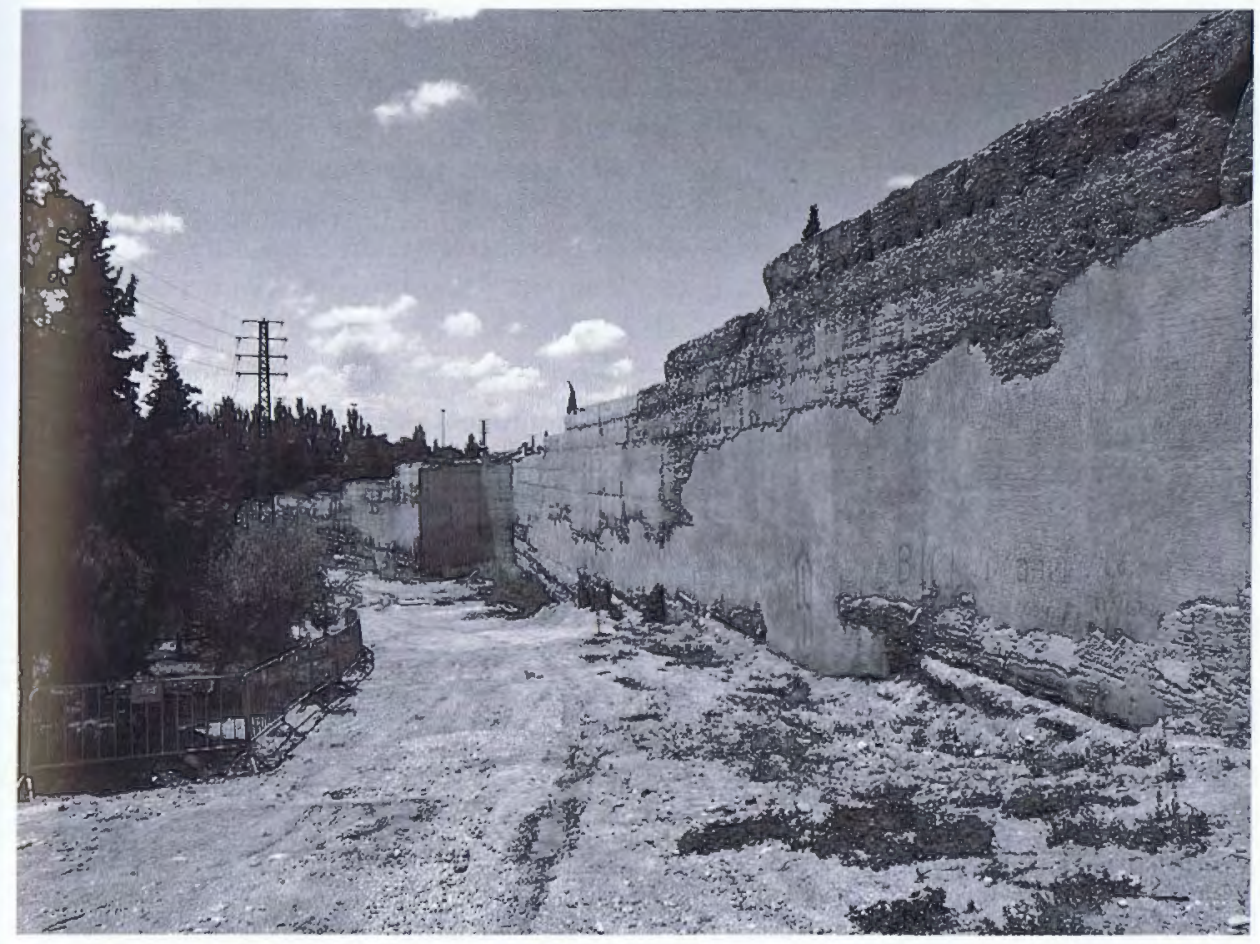

Figure 10. The restoration of the Albaicin city wall at Granada, by F. J. Gallego and J. M. López Osorio, represents an example of the new type of interventions in the last twenty years in Spain, as the country shifted from an emphasis on cutting-edge modernity to positions similar to the rest of the world, with greater respect for the principles of the discipline. (Vegas and Mileto)

of restoration in Spain has moved toward the professional philosophy of the rest of the world, showing greater respect for the principles of the discipline (Fig. 10).

\section{Appendix}

Gabriel Alomar Esteve (1910-97): town planner, General Commissioner of the Service of Defense of the National Artistic Heritage (1963-65), and collaborator in the Cultural Protection Council for the Protection of Cultural Heritage of Europe (1965-75). He is best known for his works and publications regarding historic cities, including his "Policy of Principles for the Protection of Ancient Spanish Cities," published in 1964 as part of the series Instructions for the Defense of Historic-Artistic Sites (Service for the Defense of the National Artistic Heritage of the Ministry of National Education).

Adolfo Florensa Ferrer (1889-1968): an architect and professor at the Barcelona School of Architecture. Although he designed some outstanding buildings for the city of Barcelona, he is best known for his interventions on monuments such as the Atarazanas (shipyards) in Barcelona (1957-66), Barcelona cathedral (1965), and the Monastery of Poblet (1957/62). 
Manuel González Varcárcel (1913-92): Conservation Commissioner of the Section of Castles in 1964. He was the architect of the General Department of Fine Arts all his working life. He carried out the restoration of monuments in the area of Toledo and Castilla La Mancha, where he restored the Corral de las Comedias (open-air theater) in Almagro (Ciudad Real), the Romantic Museum in Madrid, and the Teatro Real de Madrid (1966).

Francisco Íñiguez Almech (1901-82): an architect and a professor at the Madrid School of Architecture. He primarily devoted himself to the theory of architecture and the restoration of monuments, rehabilitating important monuments in Álava, Burgos, Logroño, Huesca, Navarra, and Zaragoza. In 1939, he was appointed General Commissioner of the National Artistic Heritage, a post in which he continued until he resigned in 1964. In 1958, he began his most famous restoration on the Aljafería in Zaragoza, for which he was granted the Magdalena Award in 1964.

Luis Menéndez-Pidal (1893-1975): an architect dedicated to the restoration of monuments who restored over two hundred buildings in his fifty-five years as an architect (1920-75). He was the monument conservation architect of the area of Galicia, Asturias, and León, where he carried out important restoration works including the church of Santa María del Naranco (Oviedo), the Holy Chamber in Oviedo, the Zamora cathedral, Guadalupe Monastery (Cáceres), and others. This last intervention was presented by MenéndezPidal at the Second International Congress of Architects and Technicians of Historic Monuments in Venice in 1964.

Francisco Pons-Sorolla Arnau (1917-2011): grandson of the famous painter Joaquín Sorolla and son of María Sorolla and the painter Francisco Pons Arnau. He was Monument Conservator for forty years (1945-85), engaged in restoring monuments particularly in Galicia. He was also responsible for interventions on historic town centers and was appointed conservator of the city of Santiago de Compostela.

Miguel Oliva Prat (1922-74): an archaeologist. He was the director of the Archaeological Museum of Barcelona, a professor at the Universidad de Barcelona and the director of the Ullastret site. He was the director of the Provincial Service of Archaeological Research, Conservation, and Classification of Monuments of the Diputación de Gerona, and in this capacity he presented his paper in Venice in 1964.

\section{References}

1. ICOMOS, The Monument for the Man: Records of the II International Congress of Restoration (Venice: Marsilio Ed., 1971).

2. Eleven names appear in the list of participants of the Venice congress. Of these eleven, five presented a paper. For some unknown reason, the authors of the other three papers were not reflected in the list of eleven.

3. G. Alomar, "Conférence Introductive," in ICOMOS, The Monument for the Man: Reconds of the II International Congress of Restoration (Venice: Marsilio Ed., 1971). 
4. P. Gazzola and R. Pane, "Proposte per una carta internazionale del restauro," in ICOMOS, The Monument for the Man: Records of the II International Congress of Restoration (Venice: Marsilio Ed., 1971).

5. A. Florensa, "Mise en valeur de l'enceinte romaine de Barcelone," in The Monument for the Man: Records of the II International Congress of Restoration (Venice: Marsilio Ed., 1971).

6. For more information about the relationship between Pane and Gazzalo and the themes of the debates that they shared, see: A. Pane, "Piero Gazzola, Roberto Pane e la genesi della Carta di Venezia," in A. Di Lieto and M. Morgante, Piero Gazzola. Una strategia per $i$ beni architettonici nel secondo novecento (Verona: Cierre Ed. 2009), 307-16.

7. M. González-Valcarcel, "Les travaux réalisés par la Direction Générale des Beaux-Arts à Tolède," in ICOMOS, The Monument for the Man: Records of the II International Congress of Restoration (Venice: Marsilio Ed., 1971).

8. M. Gonzallez-Valcarcel, "Utilisation des monuments à des fins culturelles," in ICOMOS, The Monument for the Man: Records of the II International Congress of Restoration (Venice: Marsilio Ed, 1971).

9. J. Bassegoda, L'Estudi de Gaudi (Barcelona: Temple Expiatori de la Sagrada Familia, 1996): 318; F. Igniguez, "Mise en valeur des monuments et des ensembles monumentaux," in ICOMOS, The Monument for the Man: Records of the II International Congress of Restoration (Venice: Marsilio Ed., 1971).

10. An exhaustive study of the life and works of Luis Menéndez-Pidal is presented by M. Martinez Monedero, Las restauraciones arquitectónicas de Luis Manéndez Pidal. La confianza de un método (Valladolid: Universidad de Valladolid, 2008). Other essays about the architect include M. Martinez Monedero, "Las restauraciones arquitectónicas de Luis Menéndez-Pidal, arquitecto de la primera zona," Loggia: Arquitectura y restauración 20 (2007): 8-23; L. Menéndez-Pidal, "Revitalisation de monuments religieux. Le Monastère de Guadalupe," in ICOMOS, The monument for the man. Records of the II International Congress of Restoration (Venice: Marsilio Ed., 1971).

11. This architect's work has been thoroughly studied by Belén Maria Castro Fernández, both in her doctoral thesis and in other essays: B.M. Castro Fernández, "Prancisco Pons-Sorolla y Arnau, arquitecto-restaurador: sus intervenciones en Galicia (1945-1985)" (Ph.D. thesis, Universidade de Santiago de Compostela, 2007); B.M. Castro Fernández, "Rescate e interpretación del patrimonio cultural: la labor del arquitecto Prancisco Pons-Sorolla en Galicia," in P. García, M.E. Almarcha, and A. Hernández, Restaurando la memoria. España e Italia ante la recuperación monumental de posguerra (Gijón: TREA, 2010), 93-117; F. Pons-Sorolla, Trasporto di monumento in Spagna. La cittadina di Puertomarin (Lugo)," in ICOMOS, The Monument for the Man: Records of the II International Congress of Restoration (Venice: Marsilio Ed., 1971).

12. Cf. B. M. Castro Fernández, "Rescate e interpretación del patrimonio cultural: la labor del arquitecto Francisco Pons-Sorolla en Galicia," in P. Garcia, M. E. Almarcha, and A. Hernández, Restaurando la memoria. España e Italia ante la recuperación monumental de posguerra (Gijon: TREA, 2010), 108-9.

13. R. Calvet Serra, "Suggestion pour la restauration des monuments," in ICOMOS, The Monument for the Man: Records of the II International Congress of Restoration (Venice: Marsilio Ed., 1971).

14. M. Oliva Prat, "La restauration monumental dans les environs de Gerona (Espagne): son apport a l'histoire de l'art," in ICOMOS, The Monument for the Man: Records of the II International Congress of Restoration (Venice: Marsilio Ed., 1971).

15. The work of this architect was rescued only recently in the research carried out by Miguel Martinez Monedero: M. Martínez Monedero, "Anselmo Arenillas y la segunda zona monumental (1940-1958)," in P. Garcia, M.E. Almarcha, and A. Hernández, Restaurando la memoria. España e Italia ante la recuperación monumental de posguerra (Gijón: TREA, 2010), 119-54.

16. J.M. Calama and A. Graciani, La restauración monumental en España de 1900 a 1936 (Sevilla: Universidad de Sevilla, 2000), 66.

17. I. Gonzáles Varas, Conservación de Bienes Culturales (Madrid: Cátedra, 1999), 513.

18. AA.VV., Veinte años de restauración monumental de España. Catálogo de la Exposición. Madrid 1858 (Madrid: Ministerio de Fomento, 2001; Reprinting of the catalogue published in 1958).

19. C. Mileto and F. Vegas, "Die Rekonstruktion in Italien und Spanien," in U. Hassler and W. Nerdinger, Das Primzip Rekonstruktion (Zurich: ETH Zürich, 2010), 240-42; C. Mileto and F. Vegas, "Alcázar von Toledo," in W. Nerdinger (coord.), Geschichte der Rekonstruktion, Konstruktion der Geschichte (Munich: 
Prestel Verlag, 2010), 283-85; I. Gonzáles Varas, Conservación de Bienes Culturales (Madrid: Cátedra, 1999), 311.

20. P. García Cuetos, "Presentación," in P. Garcia, M. E. Almarcha, and A. Hernández, Restaurando la memoria. España e Italia ante la recuperación monumental de posguerra (Gijón: TREA, 2010), 9.

21. A. Hernández, "La actuación de la Dirección General de Bellas Artes en Aragón (1938-1958). La labor de los arquitectos conservadores Manuel Lorente Junquera and Fernando Chueca Goitia," in P. Garcia, M. E. Almarcha, and A. Hernández, Restaurando la memoria. España e Italia ante la recuperación monumental de posguerra (Gijón: TREA, 2010), 43; J. F. Leujene, "The Intellectual Pleasure of Ambiguity: the Reconstruction of Spain in the Years of Autarky (1939-1956)," in M. Hardy, The Venice Charter Revisited: Modernism, Conservation and Tradition in the 21st Century (Cambridge: Cambridge Scholars Publishing, 2008), 210.

22. L. Grassi, "L'ospedale filaretiano e la sua nuova vita dopi i restauri realizzati per la sistemazione dell'Universitá degli Studi di Milano: criteri e metodi," in ICOMOS, The Monument for the Man: Records of the II International Congress of Restoration (Venice: Marsilio Ed., 1971).

23. M. P. Garcia Cuetos, El prerrománico asturiano. Historia de la arquitectura and restauración (1844-1976) (Oviedo: Sueve Ed., 1999), 230.

24. M. Martínez Monedero, "Las restauraciones de Luis Menéndez-Pidal, arquitecto de la primera zona," Loggia. Arquitectura and restauración 20 (2007): 19.

25. Ibid., 8-23.

26. M. R. Vitale, "Il restauro in Spagna fratradizione e modernitá: il dibattito dell'ultimo ventennio," Ananke 22 (1998): 8.

27. Ibid.

28. Alberto Humanes Bustamante, Intervenciones en el patrimonio arquitectónico (1980-1985) (Madrid: Ministerio de Cultura, 1990), 15-16.

29. Ley del Patrimonio Histórico Español (Ley 16/1985), article 39.

30. M.R. Vitale, "Il restauro in Spagna fratradizione e modernitá: il dibattito dell'ultimo ventennio," Ananke, no. 22 (Florencia: Alinea, 1998): 10.

31. Alberto Humanes Bustamante, "Introducción," in A. Humanes Bustamante, Intervenciones en el patrimonio arquitectónico (1980-1985) (Madrid: Ministerio de Cultura, 1990), 14-18.

32. J. Rivera Blanco, "La restauración crítica y la problemática actual," in AA.VV. III Simposio sobre restauración monumental (Barcelona: 1993), 19-20.

33. Among them the Escuela Técnica Superior de Arquitectura of the Universidad Politécnica de Valencia, where the authors of the text teach Architectural Restoration, which is compulsory for all students. Another school that has an obligatory subject in architectural restoration is the Universidad de Granada.

34. Carlos Lavesa, ed., Proyecto de recuperación de teatros (Madrid: Dirección General de Arquitectura and Edificación, 1986); C. Maestre and G. Mingo, La arquitectura en escena. Programa de rehabilitación de teatros espafioles del siglo XIX (Madrid: MOPT, 1992), Manuel De Las Casas, "La recuperación de los teatros del s. XIX," in Proyecto de recuperación de teatros, ed. C. Lavesa (Madrid: Dirección General de Arquitectura and Edificación, 1986), 7-8; P. Iglesias, J. L. Rodríguez-Noriega, and E. Tuñón, "Rehabilitación Teatro Rojas. Toledo," Arquitectura 274 (1988): 66-67; These reflections are included in part of an unpublished lecture by Juan Francisco Noguera, Professor at the Universidad Politécnica de Valencia, at the IUAV Escuela de Arquitectura-Universidad degli Studi di Venezia in November 2003. Noguera Giménez, Juan Francisco, II restauro in Spagna dal 1975 ad oggi, unpublished notes for the lecture delivered at IUAV-Universitá di Venezia, November 28, 2003 (translation into Spanish by C. Mileto), courtesy of the author.

35. A. Mernández, "Reflexiones sobre la historia reciente de la restauración monumental en España," Records of the IV Bienal de Restauración Monumental en España (Madrid, 2010), 44; Francisco Jurado, "Rehabilitación de la casa castillo de Bétera, Valencia," Monografia, no. 385-86 (Madrid: Instituto Eduardo Torroja, 1987); Francisco Jurado, "Rehabilitación de la casa-castillo de Bétera, Valencia," in Jornadas sobre restauración and conservación de monumentos (Madrid: Dirección General de Bellas Artes and Archivos, 1991), 165-76.

36. Solà Morales Ignasi, "Dal contrasto all'analogia. Transformazioni nella concezione dell’intervento 
architettonico," Lotus International 46 (1985): 37-45; Solà Morales Ignasi, "Teorías de la intervención arquitectónica," Quaderns di Arquitectura i Urbanisme 155 (1982): 30-37; Solà Morales Ignasi, Intervenciones (Barcelona: Gustavo Gili, 2006); Redacción, "Barcelona, se inicia la reconstrucción del Liceo," Arquitectura Viva 44 (1988): 5; Redacción, "El Liceo: un año and medio de su reapertura," Arquitectura Viva 56 (2014): 9; F. Vegas and C. Mileto, "Gran Teatre del Liceu, Barcelona, Spanien," in Geschichte der Rekonstruktion, Konstruktion der Geschichte, ed. Winfried Nerdinger (Munich: Presel Verlag, 2010), 292-94; Ignasi Solà-Morales, C. Cirici and F. Ramos, "Reconstrucción del Pabellón Alemán de Barcelona," Arquitectura 261 (1986): 5-15; Ignasi Solà-Morales, "Pabellón Alemán de Barcelona," El Croquis 26 (1980): 4-10; Ignasi Solà-Morales, "Proyecto de reconstrucción del pabellón de Mies Van der Rohe," El Croquis 9-10 (1983): 59-63.

37. Juan Navarro Baldeweg, "Molinos del nó Segura," El Croquis 54 (1992): 58-73; Juan Navarro Baldeweg, "Rehabilitación de los molinos del río Segura de Murcia para centro cultural and Museo Hidráulico," Arquitectura 244 (1983): 49-52; Juan Navarro Baldeweg, "Rehabilitación de los molinos del río Segura," Obradoiro 11 (1985): 52-56; J. A. Martínez-Lapeña and E. Torres, "Restauración en el castillo de Bbiza," Arquitectura 247 (1984): 43-49.

38. Pérez Arroyo Salvador, "10 anni dopo: il restauro in Spagna," TeMa 1 (1997): 2-4.

39. Mora Susana, "Dos monumentos, dos intervenciones: los monasterios de Gradefes and Carracedo (Castilla and León, España)," Informes de la Construcción 428 (1993): 39-48; S. Arroyo Pérez, J. Mañoso, and S. Mora, "El monasterio de Carracedo. León," in VVAA, Monumentos and proyecto. Jornadas sobre criterios de intervención en el patrimonio arquitectónico (Madrid: Ministerio de Cultura, 1987), 140-59; S. Arroyo Pérez, J. Mañoso, and S. Mora, "El monasterio de San Pedro de Arlanza. Burgos," in VVAA, Monumentos and proyecto. Jornadas sobre criterios de intervención en el patrimonio arquitectónico (Madrid: Ministerio de Cultura, 1987), 160-69.

40. Gil Hernández and Dionisio, "El templo de Diana. Mérida," in VVAA, Monumentos and proyecto. Jornadas sobre criterios de intervención en el patrimonio arquitectónico (Madrid: Ministerio de Cultura, 1987), 102-9; Gil Hernández and Dionisio, eds., Proyectos de intervenciones del Ministerio de Cultura. 19821986 (Madrid: El Croquis Editorial, 1986); Gil Hernández and Dionisio, "Notas sobre la política de restauración de la Dirección General del Patrimonio," Arquitectura 226 (1980): 17; Martín Almagro Basch, "Vicisitudes de las ruinas de Segóbriga and problemas de su estudio and restauración," in Arqueologia de las ciudades modernas superpuestas a las antiguas. Zaragoza 1983, ed. A. Beltrán (Madrid: Ministerio de Cultura, 1985), 17-33; M. Almagro, "El teatro romano de Segóbriga," in El teatro en la Hispania romana. Actas del Simposio (Badajoz, 1982), 25-38.

41. Antón Capitel, "El tapiz de Penélope. Apuntes sobre las ideas de restauración e intervención arquitectónica," Arquitectura 244 (1983): 24-34; Antón Capitel, "La analogía como instrumento proyectual en los edificios histónicos," in Arquitectura recuperada, coord. F. Pol (Madrid: UIMP-Cuenca, 1989), 12-19, 56; José Ignacio Linazasoro, "Reconstrucción de la Iglesia de Santa Cruz en Medina de Rioseco (Valladolid), 1987," Arquitectura 273 (1988); José Ignacio Linazasoro, "Restauración de la Iglesia de Santa Cruz en Medina de Rioseco (Valladolid)," Arquitectura 257 (1985); José Luis Linazasoro, "ll progetto di restauro della chiesa di Santa Cruz di Medina de Rioseco (Valladolid)," Restauro \& Città 5-6 (1988).

42. Antonio González Moreno-Navarro, La restauración objetiva (Método SCCM de restauración monumental), Memoria SPAL 1993-98, vol. 2 (Barcelona: Diputación de Barcelona, 1999).

43. Antonio González Moreno-Navarro, "Acabar con la magia sin dejar el método. La restauración de San Pere de Serralonga," Loggia: Arquitectura \& Restauración 8 (1999); Antonio González Moreno-Navarro, "Lugar, memoria and restauración. El cementerio de Castellnou de Bages (Barcelona)," Loggia: Arquitectura \& Restauración 11 (2001): 60-73; Antonio González Moreno-Navarro, "Restauración de la Iglesia del Castillo de Castelldefels," Loggia: Arquitectura \& Restauración 3 (1997): 44-59; Antonio González Moreno-Navarro, "Falso histórico o falso arquitectónico, cuestión de identidad," Loggia: Arquitectura y Restauración 1 (1996): 16-23.

44. The following works should be included among possible examples of this line of intervention: Javier Gallego Roca on the battlements of the Albaicin in Granada; José Manuel López Osorio on several castles in Andalusia; Ricardo Sáez on the cathedral of Santiago de Compostela, etc. The interventions of the authors of this text, both on traditional and monumental architecture, should also be included in this same line of thought. 